\title{
Effect of Chemotherapy on Malnutrition in Geriatric Group With Metastatic Colorectal Cancer
}

\author{
ㄴ) Esat Namal
}

\author{
Department of Medical Oncology, \\ İstanbul Bilim University Faculty of \\ Medicine, İstanbul, Turkey \\ Submitted: 13.09.2018 \\ Accepted: 08.10.2018 \\ Correspondence: Esat Namal, \\ İstanbul Bilim Üniversitesi Tıp \\ Fakültesi, Medikal Onkoloji Bilim \\ Dalı, İstanbul, Turkey \\ E-mail: esatnamal2000@yahoo.com

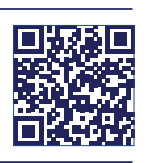 \\ Keywords: Geriatric \\ oncology; malnutrition; \\ metastatic colorectal cancer.
}

\begin{abstract}
Objective: Malnutrition in geriatric patients with colorectal cancer (CRC), especially those who received chemotherapy $(C T)$, is a frequent condition. The aim of this study was to determine the effect of CT on malnutrition in patients with geriatric metastatic CRC ( $\mathrm{mCRC}$ ).

Methods: A total of 136 patients aged 70 years and older, and diagnosed with $\mathrm{mCRC}$, were enrolled in the study. The nutritional status of the patients was evaluated with the Nutritional Risk Score-2002 before CT and after one CT course.

Results: The median follow-up time was 18.5 months. The median age was 74 . The ECOG performance score of all patients was 0 or $1.62 .5 \%$ had liver metastasis, $26 \%$ had lung metastasis, $25 \%$ peritoneal metastasis, and $8 \%$ bone metastasis. It was determined that $17.3 \%$ of patients were malnurished, and $24.6 \%$ had a risk of malnutrition. $49.4 \%$ of patients with preCT weight loss have begun. The average weight loss before the first CT was $12.1 \%$, and the incidence of malnutrition after one course of CT was $46.4 \%(p=0.00 \mathrm{I})$.
\end{abstract}

Conclusion: Malnutrition is frequently observed in patients with geriatric $\mathrm{mCRC}$, and even a single course of CT increases malnutrition in patients.

\section{INTRODUCTION}

Colorectal cancer (CRC) is one of the most common cancers worldwide, and its frequency increases with age. ${ }^{[l]}$ CRC is most commonly seen between the ages of 65 and 74 , according to the SEER database. Malnutrition is a common condition in oncology patients from the geriatric age group, with a prevalence ranging from $30 \%$ to $85 \%,{ }^{[2]}$ especially in the gastrointestinal system cancers. ${ }^{[3]}$ Especially in the elderly, malnutrition has a bad effect on mortality and morbidity, ${ }^{[4]}$ and for this reason, it is important to determine it and make a treatment plan early.

The most common causes of malnutrition in patients with CRC are mechanical causes due to tumor obstruction, decreasing appetite due to the disease itself, and therapeutic side effect. ${ }^{[5]}$ Complications caused by malnutrition lead to increased health care costs. ${ }^{[6]}$ Unwanted results caused by malnutrition are immune system degradation, delayed in-wound healing, decreased muscle strength, impaired performance, difficulty in toleration of side effects due to chemotherapy, and decreased response to chemotherapy (CT). ${ }^{[7,8]}$

The nutritional risk score (NRS-2002) evaluation form has been proposed by the European Society of Parenteral and Enteral Nutrition (ESPEN) to be used especially in nutri- tional evaluation, developed in 2002. This test is not particularly for the elderly, but it can be used in the elderly. It includes nutritional information and comorbidities and increased nutritional needs. It helps to determine the patients who need nutritional supplements.

In this study, we aimed to analyze the incidence of malnutrition before and after treatment in patients with metastatic colorectal cancer (mCRC) aged 70 years and older, by using the NRS-2002 evaluation form.

\section{MATERIAL AND METHODS}

A total of $136 \mathrm{mCRC}$ patients aged 70 years and older, who presented to our clinic from May 2014 to January 2018 , were enrolled in the study. We evaluated patients' nutritional status using the NRS-2002 form. At our center, we complete this form for every patient who receives CT. Pre- and post-chemotherapy forms of $\mathrm{mCRC}$ patients over 70 years of age were evaluated.

The NRS-2002 is a nutrition screening tool, based on randomized controlled trials developed by Kondrup et al..$^{[9]}$ According to NRS-2002, nutritional support indication is associated with comorbid diseases and the degree of malnutrition. The NRS-2002 form examines the weight loss, body mass index (BMI) and oral intake, and severity of the 
disease. Nutritional risk is defined by the current nutritional condition and comorbid disease, which is likely to disrupt the nutritional condition. There are two separate sections of this test. The first part consists of four questions (Table I). In the second part, the scores obtained from both columns are collected (Table 2). If the score is greater than 3, the patient is at a nutritional risk, and nutritional support begins. If the score is less than 3 , the patient should be scanned once a week.

All patient details are retrospectively evaluated from medical records. Patients' age, gender, tumor histology, location of tumor, results of genetic analysis, performance scores (according to the ECOG score), BMI, the history of adjuvant treatment, surgical interventions (colon surgery or metastasectomy), locations of metastasis, comorbidities, side effects, and final status of patients were recorded.

During the study, the patients were tested twice, first before the treatment started, and the second time after the first CT.

The SPSS 15 statistical program was used to assess the data obtained in the study. Continuous variables in dependent groups were tested using the t-test, and categorical data were tested using the chi-squared test. A p-value $<0.05$ was considered to be significant.

All procedures were in accordance with the ethical standards of the responsible institutional committee on human experimentation and with the Helsinki Declaration of

Table I. Initial screening

I IS BMI $<20.5$ ?

2 Has the patient lost weight within the last 3 months?

3 Has the patient had a reduced dietary intake in the last week?

4 Is the patient severely ill? (e.g., intensive therapy)

Yes: If the answer is "Yes" to any question, the screening in Table 2 is performed.

No: If the answer is "No" to all questions, the patient is re-screened at weekly intervals. If the patient

is scheduled for a major operation, a preventive nutritional care plan is considered to avoid the associated risk status. BMI: Body mass index, $\mathrm{kg} / \mathrm{m}^{2}$.

Table 2. Final screening

Impaired nutritional

status

\begin{tabular}{|c|c|}
\hline Absent score 0 & Normal nutritional status \\
\hline Mild score I & $\begin{array}{l}\text { Weight loss }>5 \% \text { in } 3 \text { month } \\
\text { or food intake below } 50-75 \\
\text { of normal requirement in } \\
\text { preceding week }\end{array}$ \\
\hline Moderate score 2 & $\begin{array}{l}\text { Weight loss }>5 \% \text { in } 2 \text { month } \\
\text { or BMI } 18.5-20.5+\text { impaired } \\
\text { general condition or food } \\
\text { intake } 25-60 \% \text { of normal } \\
\text { requirement in preceding we }\end{array}$ \\
\hline Severe score 3 & $\begin{array}{l}\text { Weight loss }>5 \% \text { in I month } \\
(>15 \% \text { in } 3 \text { months) or BMI } \\
<18.5+\text { impaired general } \\
\text { condition or food intake } \\
0-25 \% \text { of normal requireme } \\
\text { in preceding week }\end{array}$ \\
\hline Score: & + \\
\hline Age & $\begin{array}{l}\text { If }>70 \text { years: add I to total } \\
\text { score above }\end{array}$ \\
\hline $\begin{array}{l}\text { Score <3: Weekly } \\
\text { re-screening is } \\
\text { performed }\end{array}$ & \\
\hline
\end{tabular}

Severity of disease (increase in requirements)

\author{
Absent score $0 \quad$ Normal nutritional requirements \\ Mild score I Hip fracture; chronic patients, in particular with \\ acute complications of cirrhosis" or COPD; \\ chronic hemodialysis, diabetes, oncology
}

Moderate score 2 Major abdominal surgery," stroke," severe pneumonia, hematological malignancy

Severe score 3

Head injury, ${ }^{*}$ bone marrow transplantation, intensive care patients (APACHE >10)
$=$ Total score

Score $>3$ : The patient is nutritionally at risk and nutritional care plan is initiated 
1964 and its later amendments. An informed consent form was signed by all patients who participated in the study.

\section{RESULTS}

In our study, a total of 136 patients were enrolled, and the median follow-up was 18.5 months. The median age was 74 years. Of the patients, $59.1 \%$ were male, and $40.9 \%$ were female. When tumor histology was evaluated; $84 \%$ were adenocarcinoma, $9 \%$ were mucinous carcinoma, and $7 \%$ were signet ring cell carcinoma. All patients had an ECOG performance score of 0-2. A total of $55.4 \%$ of the patients were primarily operated, while $29.4 \%$ of the patients received adjuvant $\mathrm{CT}$, and $18 \%$ of the patients were metastasectomized. When the location of metastasis is addressed, metastasis was identified in the liver by $62.5 \%$, lung by $26 \%$, peritoneum by $25 \%$, bone by $8 \%$, and ovaries by $1.5 \%$. Demographic characteristics of patients are presented in Table 3.

A total of $33.6 \%$ of the patients showed no weight loss in the first assessment, while weight loss was detected in $66.4 \%$ the patients. The mean weight loss in the first assesment was $12.1 \% \mathrm{df}$.

Patients with the NRS-2002 score 3 were malnourished, and nutritional support was planned; patients with the score 2 and I were patients at risk of malnutrition and were considered to be more tightly monitored patients. There was no malnutrition in patients with a score of 0 ,

Table 3. Demographic characteristics of the study sample $(n=136)$

\begin{tabular}{lcc}
\hline Variable & $\mathbf{n}$ & $\%$ \\
\hline Median age, years (range) & 75 & $(70-83)$ \\
Sex & & \\
$\quad$ Male & 94 & 69.1 \\
$\quad$ Female & 42 & 30.9 \\
Histology & & \\
$\quad$ Adenocarcinoma & 115 & 84.6 \\
$\quad$ Mucinous carcinoma & 12 & 8.8 \\
$\quad$ Signet ring cell carcinoma & 9 & 6.6 \\
Tumor location & & \\
$\quad$ Right & 19 & 14 \\
$\quad$ Left & 80 & 58.8 \\
$\quad$ Rectum & 37 & 27.2 \\
Surgery & & \\
$\quad$ Primary & 89 & 65.4 \\
$\quad$ Metastasectomy & 23 & 16.9 \\
Metastasis site & & \\
$\quad$ Liver & 89 & 65.4 \\
$\quad$ Lung & 35 & 25.7 \\
Peritoneum & 34 & 25 \\
Ovary & 2 & 1.5 \\
Bone & 13 & 9.6 \\
Locally recurrent & 3 & 2.2 \\
\hline
\end{tabular}

Table 4. Nutritional Risk Screening 2002 values of patients at first visit and after receiving one course of computerized tomography

\begin{tabular}{lcccccc}
\hline $\begin{array}{l}\text { NRS-2002 } \\
\text { score }\end{array}$ & \multicolumn{2}{c}{$\begin{array}{c}\text { First } \\
\text { evaluation }\end{array}$} & & \multicolumn{2}{c}{$\begin{array}{c}\text { Evaluation } \\
\text { after } \mathbf{C T}\end{array}$} & p \\
\cline { 2 - 3 } & $\mathbf{n}$ & $\%$ & & $\mathbf{n}$ & $\%$ & \\
\hline Score 0 & 85 & 62.5 & & 77 & 56.6 & \\
Score I & 20 & 14.7 & & 8 & 5.8 & \\
Score 2 & 13 & 9.5 & & 10 & 7.4 & \\
Score 3 & 18 & 13.3 & & 41 & 30.2 & 0.001 \\
\hline CT: Computed tomography; NRS: Nutritional Risk Screening. &
\end{tabular}

and the NRS-2002 scores were evaluated upon each visit. According to the NRS-2002 evaluation, the risk of malnutrition after one course of chemotherapy was significantly increased in patients without the risk of malnutrition at the first control $(p=0.00 \mathrm{l})$

Eighteen patients who were diagnosed as malnurished by NRS-2002 in the first assessment, were still malnurished after receiving a course of CT (score 3 ). There were 33 patients who were found to be at risk of malnutrition in the first assessment (scores I and 2), 12 patient's risk of malnutrition after a CT are ongoing, and the remaining 21 patients developed malnutrition. Out of 85 patients who were considered well nourished in the first assessment, 2 patients developed malnutrition (score 3 ), and 6 were found to be at risk of malnutrition (scores I and 2) (Table 4).

The BMI of $46.4 \%$ of 136 patients was within the normal limits, of whom $3.0 \%$ had a normal nutritional status (NRS-2002; score, 0). However, 7I.2\% of those patients had the NRS-2002 score I, and $25.8 \%$ had the NRS-2002 score 2 .

\section{DISCUSSION}

Malnutrition is common in metastatic cancer and is closely related to mortality and morbidity. ${ }^{[10]}$ In addition, the risk of malnutrition increases during the treatment of cancer with $\mathrm{CT}^{\left[{ }^{11}\right]}$ The frequency of malnutrition in adult cancer patients ranges between $11 \%$ and $44 \%$, while in geriatric cancer patients, the frequency ranges between $29 \%$ and $61 \% .{ }^{[12]}$

The quality of life decreases in patients who develop malnutrition, and the response to cancer treatment is bad. [II] The frequency of malnutrition in patients with the gastrointestinal cancer is $50 \%-85 \% .{ }^{[13]}$

In this study, we aimed to analyze the incidence of malnutrition before and after treatment in patients with $\mathrm{mCRC}$ aged 70 years and older, by using the NRS-2002 evaluation form.

There are many malnutrition screening tools, but there is no gold standard. The NRS-2002 test has been proposed by the ESPEN to be used especially in nutritional evaluation. It was developed in 2002 and intended for hospital- 
ized adult patients. It helps to identify patients who need nutritional supplements. The weak side of NRS-2002 is that it accepts patients who have a BMI $<20.5 \mathrm{~kg} / \mathrm{m}^{2}$ in the risk group. However, in the geriatric group, a BMI below 22 $\mathrm{kg} / \mathrm{m}^{2}$ is considered a risk factor. To overcome this problem, one point is added to the calculated scores of patients over 70 years of age.

Eighteen patients diagnosed as malnurished by NRS-2002 in the first assessment were still malnourished after receiving a course of CT (score 3). Thirty-three patients were found to be at risk of malnutrition in the first assessment (scores I and 2), 12 patient's risk of malnutrition after a CT are ongoing, the remaining 21 patients developed malnutrition. Out of 85 patients who were considered well nourished in the first assessment, 2 patients developed malnutrition (score 3), and 6 were found to be at risk of malnutrition (scores $I$ and 2).

The BMI of $46.4 \%$ of 136 patients was within the normal limits, of whom $3.0 \%$ had a normal nutritional status (NRS2002 score, 0 ). However, $71.2 \%$ of those patients had the NRS-2002 score I, and $25.8 \%$ had the NRS-2002 score 2. If we evaluate the same patients according to NRS, there is a risk of malnutrition in $25.8 \%$ of patients. The conclusion is that the evaluation of patients's malnutrition using the $\mathrm{BMI}$ results alone is not an appropriate approach, and a malnutrition test must be used when evaluating patients.

The incidence of malnutrition has increased significantly with one course of CT. The increase of malnutrition disrupts the quality of life, makes it difficult to continue the treatment, and ultimately shortens survival. ${ }^{[14]}$

In our study, the mean weight loss in patients was $13.4 \%$ after one CT course. In a review that emphasizes the importance of weight loss in elderly cancer patients, the necessity of supplying nutritional supplements is also stressed. This process should be managed by a multidisciplinary team including dietitians, physicians, and nurses. ${ }^{[12]}$

The ESPEN guidelines recommend to do nutritional evaluation routinely, and when malnutrition is detected, the treatment should be conducted quickly. ${ }^{[15]}$

Muscaritoli et al. ${ }^{[16]}$ suggest that the team evaluating nutrition should do nutritional evaluation upon every visit to detect malnutrition at an early stage. If the risk of malnutrition or malnutrition is determined, nutritional support should be provided quickly.

The study by Bicakli et al. ${ }^{[17]}$ is very similar to our work, altough they have included all gastrointestinal tract malignancies, not only the patients with CRC. They have found similar results that malnutrition is very common in the geriatric cancers group, and even one course of CT significantly increased the rate of malnutrition in geriatric patients with gastrointestinal malignancy. We want to analyze the same issues for a more specific group.

In our study, the frequency of malnutrition and the effect of one course of CT on developing malnutrition were evaluated in geriatric $\mathrm{mCRC}$ patients, which is a very special group. According to these results, nutritional evaluation should be part of the examination upon every visit, especially in the geriatric group and in malignencies of the gastrointestinal system. To avoid malnutrition, a nutritional team including the medical oncologist, dietitian, physiotherapist, and nutrition nurse should evaluate patients upon every visit.

Sponsor's Role

None.

Ethics Committee Approval

Approved by the local ethics committee.

Informed Consent

Retrospective study.

Peer-review

Internally peer-reviewed.

Authorship Contributions

Concept: E.N.; Design: E.N.; Data collection \&/or processing: E.N.; Analysis and/or interpretation: E.N.; Literature search: E.N.; Writing: E.N.; Critical review: E.N.

\section{Conflict of Interest}

None declared.

\section{REFERENCES}

1. Hickson M. Malnutrition and ageing. Postgrad Med J 2006;82:2-8.

2. Swaminathan V, Audisio R. Cancer in older patients: an analysis of elderly oncology. Ecancermedicalscience 2012;6:243.

3. Brownie $\mathrm{S}$. Why are elderly individuals at risk of nutritional deficiency? Int J Nurs Pract 2006;12:110-8.

4. Chen CC, Schilling LS, Lyder CH. A concept analysis of malnutrition in the elderly. J Adv Nurs 2001;36:131-42.

5. Wildiers H, Heeren P, Puts M, Topinkova E, Janssen-Heijnen ML, Extermann M, et al. International Society of Geriatric Oncology consensus on geriatric assessment in older patients with cancer. J Clin Oncol 2014;32:2595-603.

6. van Bokhorst-de van der Schueren MA. Nutritional support strategies for malnourished cancer patients. Eur J Oncol Nurs 2005;9:S74-83.

7. Agarwal E, Marshall S, Miller M, Isenring E. Optimising nutrition in residential aged care: A narrative review. Maturitas 2016;92:70-8.

8. Bozzetti F. Why the oncologist should consider the nutritional status of the elderly cancer patient. Nutrition 2015;31:590-3.

9. Kondrup J, Allison SP, Elia M, Vellas B, Plauth M; Educational and Clinical Practice Committee, European Society of Parenteral and Enteral Nutrition (ESPEN). ESPEN guidelines for nutrition screening 2002. Clin Nutr 2003;22:415-21.

10. Balstad TR, Solheim TS, Strasser F, Kaasa S, Bye A. Dietary tretment of weight loss in patients with advanced cancer and cachexia: a systematic literatüre review. Crit Rev Oncol Hematol 2014;91:21021.

11. Aapro M, Arends J, Bozzetti F, Fearon K, Grunberg SM, Herrstedt j, et al; ESMO (European School of Medical Oncology). Early recognition of malnutrition and cachexia in the cancer patient: a position paper of a European School of Oncology Task Force. Ann Oncol 2014;25:1492-9.

12. Gaddey HL, Holder K. Unintentional weight loss in older adults. Am Fam Physician 2014;89:718-22.

13. von Meyenfeldt M. Cancer-associated malnutrition: an introduction. 
Eur J Oncol Nurs 2005;9:S35-8.

14. Tisdale MJ. Mechanisms of Cancer Cachexia. Physiol Rev 2009;89:381-410.

15. Arends J, Bodoky G, Bozzetti F, Fearon K, Muscaritoli M, Selga G, et al; ESPEN (European Society for Parenteral and Enteral Nutrition). ESPEN Guidelines on Enteral Nutrition: Non-surgical oncology. Clin Nutr 2006;25:245-59.
16. Muscaritoli M, Molfino A, Gioia G, Laviano A, Rossi Fanelli F. The "parallel pathway": a novel nutritional and metabolic approach to cancer patients. Intern Emerg Med 2011;6:105-12.

17. Bicakli DH, Ozveren A, Uslu R, Dalak RM, Cehreli R, Uyar M, et al. The Effect of Chemotherapy on Nutritional Status And Wakness in Geriatric Gastrointestinal System Cancer Patients. Nutrition 2018;47:39-42.

\section{Metastatik Kolorektal Kanser Tanılı Geriatrik Grupta Kemoterapinin Malnütrisyon Üzerine Etkisi}

Amaç: Geriatrik kolorektal (KRK) kanser hastalarında, özellikle kemoterapi (KT) sonrası malnütrisyon sık gözlenen bir durumdur. Bu çalışmanın amacı KT'nin geriatrik metastatik KRK kanseri (mKRK) hastalarında malnütrisyon durumu üzerine etkisini belirlemektir.

Gereç ve Yöntem: Kemoterapi alan 70 yaş ve üzeri 136 mKRK tanılı hasta çalışmaya alınmıştır. Hastaların beslenme durumu Nutritional risk score-2002 (NRS-2002) ile KT öncesi ve KT'den bir kür sonra değerlendirilmiştir.

Bulgular: Çalışmaya 70 yaş ve üzeri, ilk seri KT başlanacak 136 mKRK hastası alınmıştır. Median takip süresi 18.5 aydır. Ortalama yaş 74'dür. Tüm hastaların ECOG performance skoru 0 veya I'dir. \%62.5'inde karaciğer metastazı, \%26'sında akciğer metastazı, \%25'inde periton metastazı, \%8'inde kemik metastazı mevcuttur. Hastaların \%27.9'unun malnütrisyonu olduğu, \%24.6'sının da malnütrisyon riski bulunduğu belirlenmiştir. \%33.6 hastada ilk vizit öncesi kilo kaybı yoktur, \%66.4 hastada KT öncesi kilo kaybı başlamıştır. İlk vizit öncesi ortalama kilo kaybı \% I2. I'dir Bir kür KT sonrası malnütrisyon sıklı̆̆ \%46.4'e çıkmıştır $(p=0.00$ I).

Sonuç: Malnütrisyon geriatrik mKRK bulunan hastalarda sık gözlenmekte olup, tek bir kür KT bile hastaların malnütrisyonunu artırmıştır.

Anahtar Sözcükler: Geriatrik onkoloji; malnütrisyon; metastatik kolorektal kanser. 